\title{
COFINANCING IN ENVIRONMENT AND DEVELOPMENT: EVIDENCE FROM THE GLOBAL ENVIRONMENT FACILITY
}

\author{
Matthew J. Kotchen \\ Neeraj Kumar Negi \\ Working Paper 21139 \\ http://www.nber.org/papers/w21139
NATIONAL BUREAU OF ECONOMIC RESEARCH
1050 Massachusetts Avenue
Cambridge, MA 02138

May 2015

Neeraj Kumar Negi works at the GEF Independent Evaluation Office (GEF IEO). The datasets on GEF projects used for the paper were prepared by the GEF IEO and the GEF Secretariat. These were accessed after securing required permissions from the two Offices.

NBER working papers are circulated for discussion and comment purposes. They have not been peerreviewed or been subject to the review by the NBER Board of Directors that accompanies official NBER publications.

(C) 2015 by Matthew J. Kotchen and Neeraj Kumar Negi. All rights reserved. Short sections of text, not to exceed two paragraphs, may be quoted without explicit permission provided that full credit, including $($ notice, is given to the source. 
Cofinancing in Environment and Development: Evidence from the Global Environment Facility Matthew J. Kotchen and Neeraj Kumar Negi

NBER Working Paper No. 21139

May 2015

JEL No. Q01,Q2,Q54

\begin{abstract}
Leveraged cofinancing from public and private sources has emerged as a policy priority among international environment and development agencies. There is nevertheless surprisingly little research on the determinants and impacts of cofinancing for accomplishing environment and development goals. This paper contributes to the literature with a focus on three interrelated questions: (1) How does observed cofinancing depend on characteristics of the development project, the country where the project takes place, and the agencies responsible for project funding and execution? (2) What factors explain the likelihood that project cofinancing is based on loans rather than grants, and that cofinancing comes from the private sector rather than public agencies or non-governmental organizations? (3) Does greater cofinancing result in better environment and development projects? To answer these questions, we take advantage of data from the Global Environment Facility (GEF) on 3,269 projects from 1991 through the beginning of 2014. The results provide insight not only on how agencies may target cofinancing going forward, but also on how greater emphasis on cofinancing may implicitly shift environment and development priorities.
\end{abstract}

\author{
Matthew J. Kotchen \\ School of Forestry \& Environmental Studies, \\ School of Management, \\ and Department of Economics \\ Yale University \\ 195 Prospect Street \\ New Haven, CT 06511 \\ and NBER \\ matthew.kotchen@yale.edu \\ Neeraj Kumar Negi \\ Independent Evaluation Office \\ The Global Environment Facility \\ 1818 H Street, NW, Mail Stop P5-500 \\ Washington, DC 20433 USA \\ nnegi1@thegef.org
}




\section{Introduction}

Questions about how to make international aid more effective are as old as aid itself. At the macro level, some argue that not enough aid is the fundamental problem (e.g., Sachs 2005), while others argue that aid is itself detrimental to economic development (e.g., Easterly 2006). Meanwhile, at the micro level, the policy community is focused more immediately on finding ways to increase the impact of aid on a project-by-project basis. With this goal in mind, leveraged cofinancing has emerged as an increasingly important policy priority. The International Monetary Fund (2014) defines cofinancing as "the joint or parallel financing of programs or projects through loans or grants to developing countries provided by commercial banks, export credit agencies, other official institutions in association with other agencies or banks, or the World Bank and other multilateral financial institutions" (p.226). With the support of most development agencies, the basic rationale for the promotion of cofinancing is to leverage more resources from public and private sources to accomplish project, program, and development goals. ${ }^{1}$

The emphasis on cofinancing is especially pronounced in multilateral funds with a focus on environmental protection and climate change, where leveraging scarce resources is considered essential for providing global public goods at a meaningful scale. The Global Environment Facility (GEF), which has provided more than $\$ 13.5$ billion in grants for environmental projects, has made cofinancing central to its mission. GEF grants have leveraged an additional \$65 billion of cofinancing for projects in 165 developing countries (GEF 2014a), and recent policy reforms seek to increase its levels of cofinancing even further (GEF 2014b). Other examples are the Climate Investment Funds (CIFs) that operate in developing and middle-income countries to address climate change. Donor countries have contributed \$7.6 billion to the CIFs, which are expected to leverage an additional $\$ 57$ billion from other sources (CIFs 2014). More recently, pledges of more than $\$ 10$ billion to the Green Climate Fund (GCF) were made in 2014 with the expectation that the GCF will prioritize cofinancing when making funding decisions. Specifically, one of the GCF's guiding principles is "leveraging of other

\footnotetext{
1 The World Bank provides a recent and prominent example as part of the International Development Association's (IDA) $17^{\text {th }}$ replenishment. Participants identified maximizing development impact as an overarching theme and agreed that "IDA17 could not be business as usual, and welcomed the focus on leveraging private investment, public resources, and knowledge" (p. 13). Many specific recommendations were made about how the World Bank should seek to leverage greater private and public resources through cofinancing.
} 
financing, including public and private financing, seeking to maximize leverage in the case of private financing" (GCF 2013, p.17).

Advocates of cofinancing point to benefits beyond mobilizing more financial resources. Frequently heard arguments are that cofinancing promotes recipient country ownership of projects and programs; increases the likelihood of follow-up activities and stakeholder support; broadens the scope of what agencies can undertake; and helps insure that aid finances only the incremental costs to get projects and programs up and running. In many cases, the relevant ministries in recipient countries even find that demands for cofinancing help influence their own government priorities in beneficial ways. Within the push for greater cofinancing, there is also growing emphasis on the need to leverage the private sector in particular, and to employ more non-grant financial instruments, such as loans, guarantees, bonds, and equity. This is considered particularly important for environment and development projects focused on global problems, where the objective is frequently to catalyze broad and transformative impacts, with climate change being the leading example (Venugopal and Srivastava 2012; Buntaine and Pizer 2014).

But greater demands for cofinancing raise concerns as well. Critics argue that accounting for cofinancing in project development and approval can shift funding priorities from true environment and development needs to ones that simply have greater cofinancing potential. There are measurement and implementation challenges, where definitions are not always clear, and the mobilization and verification of leveraged finance takes additional staff time and resources. Recipient countries also raise concerns about how greater demands for cofinancing may promote indebtedness of poor countries rather than provide a means of more effective aid.

Despite the increasing demands for cofinancing among environment and development agencies, along with disagreement about its potential value, there is surprisingly little research on the subject. This paper contributes to the literature with a focus on three interrelated questions:

1. How does observed cofinancing depend on characteristics of the development project, the country (or countries) where the project takes place, and the agencies responsible for project funding and execution? 
2. What factors explain the likelihood that project cofinancing is based on loans rather than grants, and that cofinancing comes from the private sector rather than public agencies or non-governmental organizations?

3. Does greater cofinancing result in better environment and development projects?

We take advantage of a comprehensive data set from the GEF on 3,269 projects from 1991 through the beginning of 2014. We first estimate models to explain project cofinancing ratios - cofinancing amount over the GEF grant amount-as a function of a broad set of project, country, and agency characteristics. We then estimate models to explain the likelihood that a project receives cofinancing in the form of loans and from the private sector. A strength of the analysis is our use of fixed-effects models at the country level; this means that key results are based on variation among projects within countries. We therefore control for potentially important sources of unobserved heterogeneity based on differences among countries. The third part of our analysis takes advantage of detailed ex post evaluations of more than 650 completed projects. With these data, we estimate models that explain project outcomes related to the achievement of stated objectives and the likelihood of continued benefits after project completion. The models test for differences among project, country, and agency characteristics, but they are primarily intended to determine whether greater cofinancing results in better performing projects.

Some of our main results include the following: Larger projects are associated with greater cofinancing ratios, as are projects focused on climate change in particular. Among the agencies that lead projects, the Asian Development Bank (ADB) and the World Bank stand out as those with substantially higher cofinancing ratios, especially the ADB. Countries rated with better "government effectiveness" and "regulatory quality" host projects with higher cofinancing ratios, while better ratings for "voice and accountability" and "control of corruption" tend to lower cofinancing ratios. Larger grants and a focus on climate change increase the likelihood of loan financing and private sector involvement, and non-governmental organizations (NGOs) and foundations are more likely to execute projects with private sector involvement than are multilateral development banks (MDBs). Projects with more cofinancing are more likely to achieve favorable ex post evaluations for achieving their goals and expectations for sustained impacts, while projects with larger grants are less likely to achieve favorable ratings. Finally, projects with private sector involvement tend to achieve lower 
ratings for both project outcome and the likelihood of sustained impacts, whereas greater GDP per capita and "regulatory quality" improve project ratings in both categories.

\section{Related Literature}

We are aware of only one other study that examines the determinants of cofinancing in development projects. In a working paper for the Inter-American Development Bank (IADB), Miller and $\mathrm{Yu}$ (2012) use GEF data to study cofinancing ratios. They find that cofinancing ratios depend on whether the financing is foreign or domestic, based on grants or loans, and provided by a MDB or a United Nations (UN) agency. While Miller and Yu's (2012) analysis is similar to the first part of ours, they employ only a subset of the data that we use here, and the specifics of our econometric methods and findings differ in ways that we discuss later in the paper. One important difference, however, is that our preferred results are based on fixed effects models. Moreover, while Miller and Yu consider cofinancing ratios, they do not investigate the determinants of non-grant and private sector cofinancing or the effect of cofinancing on project outcomes.

We not aware of any study that investigates the determinants of non-grant cofinancing or involvement of the private sector. While we focus on environmentally related projects, the question is to the best of our knowledge unstudied more generally in development economics at the project level. There is a large literature that looks at how foreign aid affects private investment at a macro level, and the results are inconsistent (e.g., Papanek 1973; Harms and Lutz 2006; Herzer and Grimm 2012). Seeking to reconcile the differences, Selaya and Sunesen (2012) argue that empirical studies should not lump all aid together, but, rather, should distinguish between aid focused on complementary inputs versus substitutable physical capital. They find that the former draws in foreign direct investment while the latter crowds it out. Our focus here is on the provision of global environmental public goods, which we do not expect to crowd out private investment.

In a recent paper, Buntaine and Pizer (2014) consider whether aid directed at renewable energy facilities catalyzes private investment in clean energy. They find that aid targets countries that already have substantial private investment in renewable energy, and that greater amounts of aid do not spur additional private investment. Accordingly, Buntaine and Pizer (2014) raise questions about whether aid can effectively leverage the private sector to mitigate 
greenhouse-gas emissions through the promotion of renewable energy. Our approach is different in that we examine factors that influence private sector cofinancing alongside aid on a project-by-project basis, including projects focused on climate change and other environmental issues. Our analysis therefore seeks to identify ways to better engage the private sector and promote non-grant financial instruments up front, so that catalytic effects are more likely in the future.

The third part of our analysis considers how realized levels of cofinancing, and a broad range of other variables, explain differences in ex post project evaluations. While we are unaware of research that is directly related the study of cofinancing in this context, there is certainly a literature on project evaluation. Many of the existing studies use country-level economic, political, and social indicators to explain project rates of return (e.g., Isham et al. 1997; Isham and Kaufmann 1999) or terminal evaluations (e.g., Dollar and Levin 2005; Guillaumont and Laajaj 2006; Chauvet et al. 2010). Other studies look more specifically at how project characteristics, agency involvement, and local conditions affect project outcomes (Deininger et al. 1998; Kilby 2000; Khwaja 2009; Assefa et al. 2014). Importantly, Denizer et al. (2013) find that variation in the success of projects is greater within countries than between countries, and that inclusion of both macro and micro variables is important for explaining differences. This is the approach we take here, and we relate our specific findings to those in other studies when discussing the empirical results.

Finally, Buntaine and Parks (2013) describe how there is very little evidence on the outcome of environmental projects in developing countries beyond case studies, and they conduct an analysis of 157 environmental projects at the World Bank. Some of their main findings are that projects are more successful when countries have a stronger public sector, when the World Bank provides a greater proportion of concessional finance, and when the focus is on local benefits rather than global public goods. Several of our results are related to theirs, as we will discuss, but our analysis differs is several important ways: We study the effect of cofinancing, both the amounts promised ex ante and realized ex post; we consider two different outcome measures, one for project outcome and one for the likelihood of sustained impacts; and our data set on project terminal evaluations is significantly larger and includes observations across many agencies. 


\section{Institutional Background on the GEF}

The GEF is a multilateral fund that provides grants and concessional funding to cover the incremental costs of transforming development projects into ones that provide global environmental benefits. The GEF was established in 1991 and serves as the official financial mechanism for many international conventions. ${ }^{2}$ The GEF has several environmental focal areas: biodiversity, climate change, persistent organic pollutants, international waters, land degradation, and ozone depleting substances. To date, the GEF has disbursed $\$ 13.5$ billion that has leveraged $\$ 65$ billion in cofinancing for more than 3,900 projects in 165 developing countries.

The GEF operates through a partnership with accredited agencies that are responsible for proposing and managing GEF projects. All project proposals must first be endorsed by recipient countries, and agencies usually provide assistance to governments in developing countries or NGOs that develop and implement projects. ${ }^{3}$ Most GEF projects are one of three types - full-size projects (FSPs), medium-sized projects (MSPs), and enabling activities (EAs) - and the approval process differs by project type. ${ }^{4}$ FSPs are those with requests of more than $\$ 2$ million, and the initial concept must be approved by the GEF Council, which is a governing body of 32 members with representatives from both developed and developing countries. Once a FSP receives Council approval, the concept is developed further into a full proposal with the aim of endorsement by the GEF Secretariat and approval by the GEF Partner Agency responsible to begin implementation. MSPs are those with requests up to \$2 million and that undergo an expedited approval process whereby the Council delegates its approval to the GEF Secretariat. EAs are projects that assist countries with reporting requirements of UN Conventions and/or with information to facilitate policy and strategic decision making. EAs have a funding threshold of $\$ 1$ million. Those falling under the threshold undergo the same expedited approval process as MSPs, but those with requests greater than $\$ 1$ million follow the same approval process as FSPs. Preparation grants are also available to aid in the development

\footnotetext{
2 These are the Convention on Biological Diversity, the United Nations Framework Convention on Climate Change, the Stockholm Convention on Persistent Organic Pollutants, the United Nations Convention to Combat Desertification, and the Minamata Convention on Mercury. The GEF also supports implementation of the Montreal Protocol on Substances that Deplete the Ozone Layer for countries with economies in transition.

${ }^{3}$ There are currently 14 accredited agencies, including UN agencies, MDBs, and NGOs. The specific agencies with projects included in the data set are listed in the next section.

${ }^{4}$ Projects may also fall under programmatic approaches (PAs) or the small grants program (SGP), but we do not include projects within these categories in our analysis.
} 
of projects, with potential activities ranging from convening meetings to hiring consultants and conducting a preliminary study.

After projects begin implementation, they undergo a monitoring process that culminates with a terminal evaluation at project completion. The lead agency charged with implementing the project is responsible for completing the terminal evaluation. There are specific guidelines for reporting on progress throughout and on whether the project achieved its intended results (GEF 2008). The GEF Independent Evaluation Office (GEF-IEO) reviews the terminal evaluations to validate the findings and aggregate results across projects for lessons learned, many of which are reported in the GEF's Annual Outcome Reports. ${ }^{5}$

Every four years, as part of a replenishment process, the GEF reviews and revises its funding and strategic priorities. Policies are set about the resource allocation among focal areas and other specific programs, in addition to the allocation among recipient, developing countries. Currently, 57 percent of GEF resources are provided through country allocations to specific focal areas, and the remainder is allocated on a first-come first-serve basis within other programmatic areas. Country allocations are based on a formulaic approach that accounts for each country's potential for global environmental benefits, outcome and capacity to deliver the benefits, and equity weights based on national income. ${ }^{6}$

As part of the most recent replenishment process, which concluded in May 2014, the GEF made specific policy recommendations seeking higher levels of cofinancing (GEF 2014b) and subsequently revised its cofinancing policy (GEF 2014c). The GEF defines cofinancing as "resources that are additional to the GEF grant and that are provided by the GEF Partner Agency itself and/or by other non-GEF sources that support the implementation of the GEFfinanced project and the achievement of its objectives" (p.3). The GEF seeks to reach a cofinancing ratio of at least 6:1 for its overall portfolio, with expectations of greater cofinancing from upper-middle income countries. While the GEF does not impose minimum thresholds or require specific sources of cofinancing in the review of projects, it does engage with countries and agencies to develop strategies for achieving greater cofinancing. The aim is to "(a) enhance the effectiveness and sustainability of the GEF in achieving global

\footnotetext{
${ }^{5}$ These are available online at http://www.thegef.org/gef/APRs.

${ }^{6}$ The most recent allocations are reported in GEF (2014d). The GEF's allocation mechanism operates much like the outcome-based allocation system for each country's funding envelope in the International Development Association (IDA).
} 
environmental benefits; and (b) strengthen partnerships with recipient country governments, multilateral and bilateral financing entities, the private sector, and civil society.” (p. 3).

\section{Data Sources and Summary Statistics}

We collected and merged several data sets. This section describes the different sources of data, explains how they were combined, and presents basic summary statistics.

\section{A. Project Characteristics}

Our primary source of data is the GEF's Project Management Information System (PMIS). The PMIS includes information on all GEF projects from the initial proposal stage through project completion and evaluation. We use the PMIS data as of March $2014 .^{7}$ We consider only those projects included in the PMIS that ultimately received Secretariat approval and were not part of an interrelated programmatic approach. This means that all observations can be treated as an independent GEF project ready to receive funding. The data set consists of 3,269 projects spanning the GEF Pilot Phase through five replenishment periods (denoted GEF-1 through GEF-5), with approval dates ranging from 1991 into 2014. Figure 1 shows the number of projects by year of approval, along with an indicator for the associated GEF phase.

Central to our analysis is information on each project's level of GEF funding and cofinancing. Panel A of Table 1 reports descriptive statistics for these variables. Approved GEF grants are $\$ 3.3$ million on average, and 46 percent of the projects received a preparation grant to aid in project development. Although not reported in the table, the average preparation grant was approximately $\$ 89,000$. On average, projects had cofinancing commitments of $\$ 16$ million at the time of approval, and the average cofinancing ratio among projects - cofinancing over the GEF grant plus any preparation grant —was just under $3 .^{8}$ This means that, on average, each dollar of GEF funding allocated to a project was associated with approximately $\$ 3$ of cofinancing. But not all projects receive cofinancing: 18 percent of the projects receive no cofinancing at all. Understanding what explains variation in the cofinancing ratio at project approval is, as we will see, an important part of our analysis. There are, however, some outliers at the upper ends of the grant and cofinancing distributions that we trim in our subsequent

\footnotetext{
${ }^{7}$ Much of the PMIS data is available online at http://www.thegef.org/gef/gef_projects_funding.

${ }^{8}$ Note this is the average cofinancing ratio among projects and not the ratio for all projects collectively, which would be $\$ 16$ million / $\$ 3.3$ million $=4.85$.
} 
analysis. We drop observations in the upper 1 percent, leaving a maximum of $\$ 27$ million for the GEF grant and a maximum of 36 for the cofinancing ratio. We return to Panel $\mathrm{B}$ of Table 1 below.

We summarize categorical variables from the PMIS data in the different panels of Table 2. Most projects are FSPs, followed by EAs and MSPs. Among the focal areas, two-thirds of the projects are categorized as either biodiversity or climate change. Multi-focal area projectsones that include at least two other focal areas - are the next most common, and each of the other focal areas account for less than 10 percent. The United Nations Development Program (UNDP) is by far the most common lead agency, accounting for nearly half of the GEF projects. Other lead agencies with a substantial number of projects are the World Bank and the United Nations Environment Program (UNEP). For all other agencies, we kept distinct categories for those that account for at least one percent of the projects, while combining all others into the "Other agency" category. ${ }^{9}$ Governments were the executing partner for 76 percent of the projects. Far fewer projects were executed by multilateral agencies or NGOs, foundations, and institutes; and less than one percent was executed by the private sector. Most of the projects took place in Africa, followed by Asia, Latin American / Caribbean, and Europe / Central Asia. Though not indicated separately in the table, 10 percent of the projects are categorized as "regional" because they include more than one country within the same region. Finally, almost 8 percent of the projects are categorized as "Global" because they involve countries in more than one of the four other regions.

\section{B. Country Characteristics}

We collected data on country characteristics from the World Bank. The first is gross domestic product (GDP) per capita for each country and year. We matched the data with projects based on the year of project approval and the country where the project took place. For regional and global projects, the matching is based on the average GDP per capita of all participating countries when listed. When specific countries are not listed, the variable is left missing. As shown in Panel B of Table 1, the mean GDP per capita when averaged across projects is $\$ 3,007$ in 2013 dollars.

\footnotetext{
${ }^{9}$ The other agency category includes the GEF Secretariat with 26 projects, the African Development Bank (AfDB) with 22 projects, the European Bank for Reconstruction and Development (EBRD) with 11 projects, the World Wildlife Fund (WWF) with 2 projects, and Conservation International (CI) with one project.
} 
Other data were collected to capture potentially important dimensions of governance that could affect cofinancing and the outcome of GEF projects. We use four of the World Bank's Worldwide Governance Indicators (WGI). ${ }^{10}$ These include indices that measure governance as it relates to "voice and accountability," "government effectiveness," "regulatory quality," and "control of corruption." Each index is scaled as a percentage to reflect the number of countries in a given year that score worse than a particular country. For example, a 60 for regulatory quality in country $i$ for year $t$ means that 60 percent of the countries included in the World Bank's data set score worse on regulatory quality than country $i$ in year $t$. The WGI data is not available for every year, so when missing, we imputed data from the closest year that was available. ${ }^{11}$ This is not, however, much of a limitation because these data are primarily designed for studying cross-sectional differences among countries rather than changes over time, and this will influence how we use the WGI indicators in our statistical models. Again, for regional and global projects, we use the mean of all countries participating in the project when countries are listed, otherwise the variable is left missing. As shown in Panel B of Table 1, all of the WGI variables range from zero to above 90 and have means close to 40 .

\section{Loan and Private Sector Cofinancing}

We obtained a further data set from the GEF Secretariat that included more details on the types and sources of project cofinancing. Of particular interest is (a) whether the cofinancing was in the form of a loan, including both concessional and non-concessional loans, and (b) whether cofinancing was delivered through the private sector. We focus on loans and private sector cofinancing because of the recent initiatives to promote loans and private sector involvement at the GEF and other institutions focused on delivering environmental and development finance.

We consider loan and private sector cofinancing for only MSPs and FSPs because no EAs include loans and only two have private sector involvement. Of the 2,198 MSPs and FSPs in the data set, we obtained the more detailed cofinancing data on 1,778 (81 percent) of the

\footnotetext{
${ }^{10}$ These data are available at http://info.worldbank.org/governance/wgi/index.aspx\#home, where there is also a detailed description of the methodology. Two indicators not used in the analysis that we report here are "rule of law" and "political stability and absence of violence." We do not include these variables to minimize collinearity with the other indicators and because they never produced statistically significant results.

${ }^{11}$ Specifically, data are not available for years 1991-1995, 1997, 1999, 2001, 2013, or 2014. When first compiling the WGIs, they were produced every other year. We use data imputation such that 1996 data is used for 19911995, and for the other missing years, we use data available from the most recent previous year. Later in the paper, we report clustered standard errors for our regression models that account for the data imputation.
} 
observations. These are all of the projects for which the data are available. Twenty-two percent of the projects include loan financing, and the conditional mean amount of loan financing was 59 percent of each project's total cofinancing. Regarding private sector involvement, 38 percent of the projects had private sector involvement, and the conditional mean of private sector financing was 36 percent of a project's total cofinancing. Other sources of private sector financing were grants and in kind contributions. In our empirical analysis, we investigate the determinants of loan based cofinancing and private sector involvement in GEF projects.

\section{Project Terminal Evaluations}

Our final source of data comes from the GEF-IEO and is based on reviews of the terminal evaluations that agencies provide upon project completion. For a subset of the GEF's completed projects, the GEF-IEO conducted a detailed and independent evaluation of the terminal evaluations and created a consistent set of variables for making comparisons among projects. We use the complete set of data available from the GEF-IEO as of March 2014.

Project outcomes-The first variable is an overall evaluation of project outcomes based on stated goals. The variable is based on indicators in three dimensions: relevance to the intended focal area and country priorities; effectiveness at achieving outcomes; and efficiency with respect to costs and implementation times. ${ }^{12}$ The indicators are then combined into an overall outcome variable with six ordered categories. These data are available for 688 MSPs and FSPs. The different categories and percentages are highly satisfactory (5\%), satisfactory $(42 \%)$, moderately satisfactory (36\%), moderately unsatisfactory (13\%), unsatisfactory $(4 \%)$, and highly unsatisfactory (less than one percent). In our subsequent analysis, we convert the outcome variable into a binary indicator of satisfactory or better (47\%).

Sustainable impact-The second variable is a measure of sustainable impact, which measures the likelihood of continued project benefits after project completion. The variable is based on indicators in four dimensions: likelihood of continued financial resources; sufficient social and political interests; adequacy of institutional frameworks and governance; and environmental conditions. The overall sustainable impact variable is available for $666 \mathrm{MSPs}$ and FSPs. In this case, the evaluation is based on four ordered categories for the likelihood of

\footnotetext{
${ }^{12}$ The project outcome measure focuses on results and does not include other dimensions such as monitoring and evaluation, project design, or, importantly, cofinancing. More details on how the GEF-IEO created variables from the terminal evaluations are contained in Annex B of the GEF Annual Outcome Report 2013 (GEF 2013).
} 
sustained impacts, which are likely (15\%), moderately likely (45\%), moderately unlikely $(30 \%)$, and unlikely $(10 \%)$. When analyzing these data, we convert the categories into a binary indicator of moderately likely or better (55\%).

Actual cofinancing-The data set also includes information on the realized level of cofinancing delivered as part of project implementation. This, of course, may differ from the cofinancing numbers described previously based on intended levels of cofinancing at the time of project approval. Data on actual cofinancing is available for 610 MSPs and FSPs, and the numbers do indeed differ from those at the time of project approval. The mean amount of actual cofinancing is $\$ 17$ million, compared to the expected mean amount for these same projects of \$13 million. When conducting our analysis of variables that affect project outcomes and sustainable impact, we will use the measure of actual cofinancing. We will also account for whether actual cofinancing exceeded or fell short of the expected amount. Among the 610 projects for which the data are available, 60 percent received more than the expected amount of cofinancing.

\section{The Determinants of Cofinancing at Project Approval}

We begin with the question of what explains variation in cofinancing at the project approval stage. We first estimate a model of the form

$$
\begin{aligned}
& Y_{i j t}=\alpha \ln \left(G E F \text { grant }_{i}\right)+\beta \text { Prep }_{i}+\gamma E A_{i}+\text { SFocal }_{\boldsymbol{i}}+\boldsymbol{\theta A g e n c y}_{\boldsymbol{i}}+\text { oPart }_{\boldsymbol{i}} \\
& +\sigma \ln \left(G_{D P C a p} j t\right)+\boldsymbol{\pi} \boldsymbol{W} \boldsymbol{G I}_{\boldsymbol{j t}}+\boldsymbol{\mu} \boldsymbol{R e g i o n}_{\boldsymbol{i}}+\tau_{t}+\varepsilon_{i j t},
\end{aligned}
$$

where the dependent variable is the cofinancing ratio for project $i$ in country $j$ and approval year $t$. The independent variables are, respectively, the size of the GEF grant, an indicator for having received a preparatory grant, an indicator for an enabling activity, a categorical variable for focal area, a categorical variable for lead agency, a categorical variable for executing partner type, GDP per capita, the set of WGI indicators, and a categorical variable for region. ${ }^{13}$ The specification also controls for annual fixed effects with $\tau_{t}$, and $\varepsilon_{i j t}$ is an error term. The regional controls in specification (1) mean that coefficients are identified based on variation in

\footnotetext{
${ }^{13}$ We do not include a categorical variable to distinguish between MSPs and FSPs because of collinarity with the size of the GEF grant, which is the basis for distinction between the two categories.
} 
projects within regions after controlling for a common time trend. This is useful for estimating potential effects of the WGI indicators, which, as mentioned previously, are better equipped for cross-sectional comparisons than for differences within countries over time.

A limitation of specification (1) is that it does not control for sources of unobserved yet time invariant heterogeneity among countries that could affect cofinancing ratios. To address this concern, we estimate a fixed effects model of the form

$$
\begin{aligned}
& Y_{i j t}=\alpha \ln \left(\text { GEFgrant }_{i}\right)+\beta \text { Prep }_{i}+\gamma E A_{i}+\text { SFocal }_{\boldsymbol{i}}+\boldsymbol{\theta A g e n c y}_{\boldsymbol{i}}+\text { oPart }_{\boldsymbol{i}} \\
& +\sigma \ln \left(G D P \operatorname{cap}_{j t}\right)+v_{j}+\tau_{t}+\varepsilon_{i j t},
\end{aligned}
$$

where the only difference is inclusion of a country fixed effect $v_{i}$ in place of the WGI indicators and regional controls. This means that coefficients are identified entirely off of variation in projects within countries assuming an overall common time trend. ${ }^{14}$ When showing the results of this model and all others, we report standard errors that are clustered at the country level to account for potential unobserved correlation among projects within countries and over time.

In addition to ordinary least squares (OLS) estimates of specifications (1) and (2), we estimate corresponding Tobit models for each. The first is a pooled Tobit model, and the second is the random effects Tobit model. ${ }^{15}$ Recall that 18 percent of the projects have zero cofinancing, and this motivates estimation of the Tobit models, which are able to account for a large number of corner solutions at zero for the dependent variable (Wooldridge 2002). In particular, the Tobit model is useful for deriving marginal effects of the explanatory variables that account for the combined effects of changes in the probably of having cofinancing and changes in cofinancing conditional on having a positive amount. The Tobit models therefore provide our preferred estimates, while comparisons with the OLS models provide useful robustness checks. ${ }^{16}$

\footnotetext{
${ }^{14}$ To take advantage of all the data, we also include regional and global projects with their own fixed effects when estimating specification (2). The results do not change in any meaningful way if these observations are excluded.

${ }^{15}$ We estimate the random effects Tobit model rather than a fixed effects Tobit because the latter is not unbiased (Wooldridge 2002).

${ }^{16}$ We also estimate double hurdle models to examine the extensive and intensive margins of cofinancing ratios separately. We discuss these models and results at the end of this section.
} 
We report the results of all four models in Table 3. The first two columns contain the OLS estimates. The second two columns contain the Tobit estimates of the overall marginal effect; that is, we report the unconditional marginal effects for each independent variable evaluated at its mean. Looking across the columns, we find that the estimates are quite consistent across models. In particular, the coefficient signs, magnitudes, and statistical significance change very little between either of the two OLS models or the two Tobit models, and differences between the OLS and Tobit models are also quite small. ${ }^{17}$ Hence we focus our discussion on the Tobit results, and specifically on coefficients of the random effects estimates, unless otherwise indicated.

Whether a project receives a preparatory grant or not has an insignificant effect on a project's cofinancing ratio, yet the size of the overall GEF grant does. Because the GEF grant variable is $\log$ transformed, it can be interpreted such that a 10-percent increase in the size of a GEF grant is associated with a 0.048 increase in the cofinancing ratio. In other words, a 10percent increase in the GEF grant for the averaged sized project means that there is just under 5 cents in additional cofinancing per GEF dollar spent. EAs are associated with significantly lower cofinancing ratios, with each GEF dollar producing $\$ 1.17$ less on average. This result is not surprising because EAs tend to focus on foundational work that is less likely to attract cofinancing.

The cofinancing ratios differ across focal areas. The coefficients reported in Table 3 are interpreted relative to the omitted category of multi-focal area projects. Those with lower ratios, but not significantly different from each other, are biodiversity, ozone related, and organic pollutants. Those with higher ratios, but also not significantly different from each other, are climate change and international waters. The most notable comparison is between the GEF's two primary environmental foci: projects focused on biodiversity are associated with lower cofinancing ratios than those focused on climate change; and after controlling for other variables in the model, the average difference is 0.8 and statistically significant. Miller and $\mathrm{Yu}$ (2012) find a similar pattern of results across focal areas on a more restricted sample, though their models do not include country-level fixed effects.

\footnotetext{
${ }^{17}$ Regarding the Tobit models, a likelihood-ratio test for significance of the panel-level variance component does not reject the null hypothesis $\left(\bar{\chi}^{2}=47.32, p<0.00\right)$, implying that the overall random effects estimates are not statistically different from the pooled estimates.
} 
Regarding differences among lead agencies, the ADB stands out with the highest cofinancing ratios - a substantial 3.8 higher on average than the omitted category of the UNDP. Other agencies with higher ratios are the World Bank and the Other agency category. These are 0.86 and 0.68 higher, respectively, than the UNDP on average, but while the World Bank is generally higher than most agencies with statistical significance, the Other agency category is not. Thus the general finding is that the World Bank and ADB are associated with projects that have higher cofinancing ratios, but the $\mathrm{ADB}$ is the real standout with ratios even greater than the World Bank by 2.9 on average. These results build on Miller and Yu's (2012) finding that MDB's tend to have higher cofinancing ratios than UN agencies. We find no statistically significant differences among the executing partner types of multilateral agencies, governments, private sector, or $\mathrm{NGO} /$ foundation/institution.

With respect to country characteristics, GDP per capita has no statistically significant relationship with cofinancing ratios in any of the models. We turn to the pooled models for inference about the governance indicators, for which we focus only on the qualitative signs. In both the OLS and Tobit models, voice and accountability is associated with lower ratios, yet government effectiveness is associated with higher ratios. The former result may represent an unintended consequence of more participatory and transparent processes, while the later result shows a relationship between good governance and greater finance. With the pooled OLS estimates, there is evidence that better regulatory quality promotes cofinancing, yet greater control of corruption discourages it. The later result is interesting to the extent that reported cofinancing may not always be legitimate, perhaps being based on non-additional finance or double counting. The final set of results are related to geographic region. We find that country or regional projects are associated with greater cofinancing ratios than global projects (the omitted category). In all regions the ratios are between 0.57 and 0.84 higher, yet they are not statistically different from one another.

The preceding analysis considers how different variables affect intended cofinancing ratios at the time of project approval. A limitation of the models, however, is the assumption that a single mechanism determines whether a project has cofinancing (the extensive margin) and the amount of cofinancing conditional on having some (the intensive margin). While the OLS models do not distinguish between the two margins at all, the Tobit model assumes the sign of the two effects is the same. It is nevertheless possible that variables could have different 
effects on the extensive and intensive margins, meaning that how a variable affects whether there is cofinancing could differ from the way it affects the conditional amount of cofinancing. To explore this possibility, we estimate a "double hurdle" model that separately examines the extensive and intensive margins with (i) a linear probability model of whether the cofinancing ratio is greater than zero, and (ii) an OLS regression on only those observations with positive cofinancing ratios. We again estimate pooled and fixed effects variants of the model and report the full set of results in Appendix Table 1.

A few results are nevertheless worth highlighting. We find evidence that the focal areas of climate change and international waters have different effects on each margin. Specifically, climate change and international waters projects are less likely to have cofinancing, but conditional on having it, they have more of it. We also find differential effects with two governance indicators. Better regulatory quality decreases the odds of having cofinancing, but when there is cofinancing, better regulatory quality is associated with higher ratios. Interestingly, better control of corruption has the opposite pattern: better control increases the odds of having cofinancing, but decreases the conditional cofinancing ratio.

\section{Loan and Private Sector Involvement}

We now investigate whether project cofinancing includes (i) some amount in the form of a loan (concessional or non-concessional), and (ii) private sector involvement. Keep in mind that loans need not come from the private sector, and the private sector can support GEF projects in ways other than loans. Recall that the loan and private sector cofinancing data are available for a subset of projects analyzed in the previous section and that the data apply only to MSPs and FSPs.

We estimate linear probability models using the same general specification as that in equations (1) and (2). For one set of models, the dependent variable is an indicator for whether the project's cofinancing includes a loan. In parallel with the previous analysis, we estimate one model with regional dummies and the WGI indicators and another model with country fixed effects. The same pair of models are then estimated again with the dependent variable as an indicator for whether the project's cofinancing has private sector involvement. The only change 
in the right-hand-side variables from the previous models is exclusion of the indicator for EAs. ${ }^{18}$ Table 4 reports the results of all four models.

We first discuss the results for loans. We focus primarily on the fixed effects estimates, which control for time invariant, unobserved heterogeneity across countries. Projects with larger GEF grants are more likely to include loans: doubling the size of a GEF grant increases the probability of the project including a loan by 0.08 , or equivalently 8 percentage points. Projects that received a preparatory grant are 6 percentage points less likely to included loans. One possible explanation for this result is that a project needing more assistance in the development stage is a good indicator for whether it is less likely to generate revenue in support of loan payments.

The pattern of results for focal areas is similar to that shown previously for the overall cofinancing ratio. Climate change projects are 8 percentage points more likely to include loans than multi-focal area projects, which are not statistically different from those focused on biodiversity. The focal areas that are significantly less like to include loans are ozone related and organic pollutants.

When compared to the UNDP, all agencies are more likely to lead projects that include loans. The point estimates are such that the ADB, IADB, and the Other agency category are all more than 60 percentage points more likely. The World Bank and IFAD are also significantly more likely, by 40 and 37 percentage points, respectively. We find no statistically significant results for the executing partner type.

In the pooled linear probability model, GDP per capita is associated with a negative effect on the probability of a project including a loan. The magnitude is such that a 10-percent increase in GDP per capita decreases the probability of a loan by just under half of a percentage point. The result is not, however, statistically different from zero in the fixed effects model. None of the WGI variables is significant in the pooled model, but there is a regional pattern worth noting. When projects are based in one region, or more commonly one country, they are more likely to include a loan as part of the cofinancing. Those in Europe / Central Asia and Latin America / Caribbean are the most likely to include loans, with both being close to 15

\footnotetext{
${ }^{18}$ We also estimated standard and random-effects Probit models. We do not report these results here because the qualitative results and magnitudes of the marginal effects are so similar to those of the linear probability models. These results are, however, available upon request.
} 
percentage points more likely than a global project. Projects in Africa and Asia are also more likely, but with approximately half the magnitude.

We now turn to the private sector results in columns (3) and (4) of Table 4. Some of the results are similar to those for loans, but others are quite different. Projects with larger GEF grants are more likely to involve the private sector, though the magnitude is small. A doubling of the GEF grant increases the probability by approximately half a percentage point. Projects that received a preparatory grant are about 6 percentage points more likely to involve the private sector.

Differences between the primary focal areas of biodiversity and climate change continue to arise, with the former being almost 20 percentage points less likely to involve the private sector and being significantly less likely than multi-focal area projects. Land degradation is also significantly less likely to involve the private sector. Interestingly, the effect of ozone related and organic pollutant projects on private sector involvement differs than that for loans. Both are associated with greater private sector involvement, with magnitudes even greater than climate change, i.e., 32 and 16 percentage points greater than multi-focal area projects, respectively, compared to 11 percentage points greater for climate change.

When it comes to promoting private sector involvement, IFAD and UNIDO are the leading agencies. Compared to the UNDP, these agencies are about 25 percentage points more likely to have projects that involve the private sector. This is perhaps not surprising given that IFAD seeks to promote agricultural development and UNIDO has a specific mandate to promote private sector development. The World Bank is also associated with greater private sector involvement, but the magnitude is quite a bit smaller, at close to 6 percentage points more likely than the UNDP. It is worth noting how the ADB and IADB are not associated with greater private sector involvement, yet they were the standout agencies with respect to loans. We find only one statistically significant difference for the effect of executing partner type. When the executing partner type is a NGO/Foundation/Institution, projects are significantly more likely - i.e., 14 percentage points - to have private sector cofinancing than if the partner type is a multilateral agency. It is worth noting, however, that the executing partner type being the private sector does not mean projects received private sector cofinancing. Indeed, we do not find a significant effect of the variable on private sector cofinancing, though this is likely 
because of the small number of observations (only 15 in the regression model) that have a private sector entity as the executing partner.

In contrast to the results for loans, we find that GDP per capita increases the probability of cofinancing from the private sector. A doubling of GDP per capita increases the probability of private sector cofinancing by 5 percentage points. For the other results about country characteristics, we turn to the pooled linear probability model. We find some evidence that greater voice and accountability decreases private sector cofinancing, while greater government effectiveness increases it. Among regions, Asia is the outlier having the lowest probability of private sector cofinancing, at 11 percentage points less likely than global projects and more than 15 percentage points less than any other region.

\section{Project Outcome and Sustainable Impact}

We now turn to the analysis of terminal evaluations, from which we have two measures: project outcome related to the achievement of goals and the likelihood of sustained impacts. Recall that the evaluation data are available for a subset of the GEF's completed projects, that is, those that the GEF-IEO has covered in its independent review. Our empirical approach mirrors that from the previous section in that we estimate linear probability models to explain project outcome and the likelihood of sustained impact. For these models, we include country characteristics, but do not estimate fixed effects models because there are fewer observations upon which to identify within-country effects. Because of the fewer observations, we also control for the common time trend with GEF Phase dummies rather than a dummy variable for each year. The explanatory variables are generally the same as those used previously. The only differences are our use of actual levels of cofinancing as an explanatory variable, along with an indicator for whether actual cofinancing exceeded anticipated cofinancing at the time of project approval. We continue to report standard errors clustered as the country level.

We first consider project outcome, where the dependent variable is an indicator of whether a project achieves an outcome rating of "satisfactory" or better. We report three linear probability models in columns (1) through (3) of Table 5. We estimate the different specifications because of missing data for some of the variables. The first model excludes the cofinancing and country-characteristic variables and has 688 observations. The second model includes the cofinancing variables, but the data are missing for 96 observations, thereby 
reducing the observations in the model to 592. The third model includes the country characteristics, which are missing for some regional and global projects with unspecified countries, and this reduces the observations further to 546. Given our focus on cofinancing and the advantages of including country characteristics in the model, we prefer the estimates in column (3), upon which we concentrate discussion. It is nevertheless reassuring to see that the coefficients estimated across all three models change little when restricting the sample.

All of the financing variables have statistically significant effects on project outcome. Greater cofinancing increases the probability of a project achieving a satisfactory rating, as does having greater cofinancing than expected. A one-percent increase in the amount of cofinancing increases the probability of a satisfactory rating by 3 percentage points, and achieving greater than expected cofinancing increases the probability by 10 percentage points. Interestingly, after controlling for cofinancing, projects with larger GEF grants receive lower ratings: a one-percent increase in the GEF grant decreases the probability of a satisfactory rating by more than 6 percentage points. Finally, projects with preparatory grants also rate less well, having a lower probability of a satisfactory rating by 9 percentage points. ${ }^{19}$

There are no statistically significant differences in the outcome ratings of projects within the single focal areas. There is, however, evidence that the single focal area projects achieve higher outcome ratings. Specifically, when compared to multi-focal area projects, those with a singular focus on biodiversity, climate change, and land degradation are all more likely to achieve a satisfactory rating by at least 15 percentage points. One possible explanation is that multi-focal area projects face additional challenges of needing to satisfy outcome criteria in more than one focal area, in addition to being more complex.

We find no statistically significant differences among the lead agencies. The finding is consistent with two possible interpretations. The first is that the lead agency does not affect project outcome after controlling for the other variables. The second is that the probability of a project receiving a satisfactory rating does not depend on subjectivity of the lead agency that provided the terminal evaluation prior to the GEF-IEO's independent review. This result is of interest because of the potential for differences in evaluation criteria among agencies notwithstanding the GEF-IEO's evaluation guidelines.

${ }^{19}$ See Denizer et al. (2013) for a qualitatively similar result among World Bank projects. 
We find a particularly interesting result regarding the executing partner type. When the executing partner is from the private sector, projects tend to perform less satisfactorily. Compared to projects executed by multilateral organizations, those executed by the private sector are 31 percentage points less likely to achieve a satisfactory rating. Moreover, the multilateral organizations are not statistically different from governments or the $\mathrm{NGO/Foundation/Institution} \mathrm{category.} \mathrm{The} \mathrm{apparent} \mathrm{under-performance} \mathrm{on} \mathrm{the} \mathrm{outcome}$ measure by the private sector is an important result in light of the way that the GEF and other environment and development agencies - in addition to many donor countries - are seeking to promote greater private sector engagement in such projects. While we are not able to explain the mechanism underlying the result, the finding raises an important question for further research. One question worth pursuing, for example, is whether these projects tend to be more risky.

Three results for project outcome standout based on country characteristics. First, greater GDP per capita is associated with better outcomes: a one-percent increase in GDP per capita increases the probability of a satisfactory rating by just under 7 percentage points. Second, better regulatory quality within a country improves project outcomes. The magnitude of this result is such that a 10-pecrent increase in a country's rating for regulatory quality increases the probability of a satisfactory rating by 5 percentage points. This finding accords with Dollar and Levin's (2005) aggregate level result that better institutions lead to better project outcomes. ${ }^{20}$ Finally, global projects are more likely to obtain satisfactory ratings than regional or single-country projects, and while the differences among regions are not statistically significant, the magnitudes are such that Africa and Latin America / Caribbean projects are less likely to be satisfactorily rated. Dollar and Levin (2005) find a similar result for World Bank projects in Africa.

We turn now the results for the likelihood of sustained impacts. These models are reported in columns (4) through (6) in Table 5, and the dependent variable is the only difference from the corresponding models in columns (1) through (3). We are now focused on explaining the probability that a project is at least "moderately likely" to have sustained impacts. Projects are more likely to have sustained impacts if they have greater amounts of

\footnotetext{
${ }^{20}$ We do not find a statistically significant effect of "government effectiveness." This result contrasts with that in Butaine and Parks' (2013) study of environmentally related projects at the World Bank.
} 
cofinancing, if actual cofinancing exceeds anticipated cofinancing, and if the overall GEF grant is smaller. These results all have the same sign and similar magnitudes as those for project outcome. One difference is that the effect of preparatory grants is statistically insignificant for sustained impacts.

The results differ somewhat among environmental focal areas. Ozone related projects are, by a large margin, those most likely to have sustained impacts, being 54 percentage points more likely than multi-focal area projects. Because ozone related projects typically involve changes to production practices based on the diffusion of a new technology, this result may not be particularly surprising. Climate change and international waters are the other focal areas associated with greater likelihoods of sustained impacts, where the magnitudes are estimated with reasonable amounts of statistical precision.

Several other results standout. The UNDP appears to be an outlier with regard to its leading on projects that are less likely to have sustained impacts. Compared to the Other agency category, UNDP projects are 37 percentage points less likely to rate at least moderately likely for sustainable impacts. The UNDP ratings are also significantly less likely than those for UNEP, UNIDO, and the World Bank. However, as indicated above, interpretation of this result should be done with caution because we are not able to distinguish whether this is due to differences in the initial ratings that UNDP submits, in some unobserved characteristic of UNDP projects, or in actual outcomes. We again find a large and statically significant result when the executing agency is from the private sector: compared to all other types, projects executed by the private sector are about 30 percentage points less likely to have sustained impacts. While we find no statistically significant results for GDP per capita or the WGI indicators, we do find that projects in Africa are less likely to have sustained impacts, and the magnitude of this result is substantial: African projects are significantly less likely than all other regions and 17 percentage points less likely than global projects.

\section{Conclusions}

Leveraged cofinancing from public and private sources has emerged as a policy priority among international environment and development agencies as a means for accomplishing environmental and development goals. This paper contributes to the literature with a focus on the determinants and impacts of cofinancing in the largest and longest running multilateral fund 
focused on global environmental problems and sustainable development. We motivate the analysis with three questions and use them again to organize a qualitative summary of our main results.

How does observed project-level cofinancing depend on project characteristics, country characteristics, and the agencies responsible for project funding and execution? We find that larger projects are associated with greater cofinancing ratios, as are projects seeking to address climate change compared to other environmental challenges. The ADB and the World Bank stand out as leading projects with substantially higher cofinancing ratios, especially the ADB. We find evidence that a country's ratings of better "government effectiveness" and "regulatory quality" are associated with higher cofinancing ratios, while greater "voice and accountability" and "control of corruption" are associated with lower ratios. More globally focused projects tend to have lower cofinancing ratios.

What factors explain the likelihood of loan cofinancing and private sector involvement? Projects with larger grants and a focus on climate change are more likely to have both loan cofinancing and private sector involvement. Projects that receive a preparatory grant are less likely to receive a loan, yet more likely to have private sector involvement. The same pattern arises for projects focused on reducing ozone and organic pollutants. Institutions more likely associated with projects that include both loan cofinancing and private sector involvement are IFAD, UNIDO, and the World Bank. In contrast, the ADB and the Asia region more generally are strongly associated with loan cofinancing but not private sector involvement. NGOs and foundations are more likely to execute projects with private sector involvement than the MDBs. Finally, countries rated as having greater "voice and accountability" are less likely to have private sector involvement, while those with greater "government effectives" are more likely.

Does greater cofinancing result in better environment and development projects? The answer to this question appears to be "yes." Projects that have greater cofinancing are more likely to achieve higher ex post evaluations for both outcome satisfaction and sustained impacts. These results hold even though projects with larger grants are less likely to achieve favorable ratings. Among the environmental focal areas, climate change projects are the only ones likely to achieve more favorable ratings for both outcome satisfaction and sustainable impacts. The UNDP is the only lead agency that stands out as being associated with lower ratings for sustainable impacts, but there are qualifications to this result that we have discussed 
previously. Projects executed by the private sector tend to achieve lower ratings for both project outcome and sustainable impacts. Greater GDP per capita and "regulatory quality" of a host country increase project outcome, yet projects in African countries tend to achieve lower ratings in both of the performance measures.

The result presented in this paper have broader implications going forward. Greater demands for cofinancing are emerging in a wide range of agencies and governments seeking to maximize the impact of aid for environment and development. The trend is clear across bilateral and multilateral development agencies, including the GEF, the CIFs, and the newly created GCF. Regarding climate finance in particular, cofinancing is considered central to achieving the necessary scale and transformative effects. In this context, our results further the understanding of how project, country, and agency characteristics are more or less associated with cofinancing, the use of loan financial instruments, and private sector involvement. We also provide the first evidence on how cofinancing affects project outcomes. Finally, while agencies and governments may use our results to target projects with greater cofinancing potential, it is important to keep in mind how doing so may implicitly shift environment and development priorities. 


\section{References}

Assefa, Y., O. Rivera, and D. Vencatachellum (2013) "Macro and Micro Determinants of Project Outcome," African Evaluation Journal, 2(1), Article \#86.

Buntaine, M. and B. Parks (2013) "When Do Environmentally Focused Assistance Projects Achieve Their Objectives" Evidence from World Bank Post-Project Evaluations," Global Environmental Politics, 13:65-87.

Buntaine, M. and W. Pizer (2014), "Encouraging Clean Energy Investment in Developing Countries: What Role for Aid?” Climate Policy, DOI:10.1080/14693062.2014-953903.

CIFs (2014), "About the Climate Investment Funds," Available on the CIFs webpage, accessed January 28, 2014 at https://www.climateinvestmentfunds.org/cif/aboutus.

Chauvet, L., P. Collier, and A. Fuster (2006) "What Explains Aid Project Success in PostConflict Situations,” World Bank Policy Research Working Group Paper No. 5418.

Deninger, K., S. Lyn, and S. Basu (1998) "Does Economic Analysis Improve the Quality of Foreign Assistance?" World Bank Economic Review, 12:385-418.

Denizer, C., D. Kaufmann, and A. Kraay (2013) "Good Countries or Good Projects? Macro and Micro Coorelates of World Bank Project Outcome," Journal of Development Economics, 105:288-302.

Dollar, D. and V. Levin (2005) "Sowing and Reaping: Institutional Quality and Project Outcomes in Developing Countries," World Bank Policy Research Working Group Paper No. 3524.

Easterly, W. (2006), The White man's Burden: Why the West's Effort's to Aid the Rest Have Done So Much Ill and So Little Good, New York, New York: The Penguin Press.

GCF (2013), Decisions of the Board-Fifth Meeting of the Board, 8-10 October 2013. Green Climate Fund, GCF/B.05.23.

GEF (2013), “GEF Annual Outcome Report 2013," Prepared by the GEF Independent Evaluation Office.

GEF (2008), "Guidelines for GEF Agencies in Conducting Terminal Evaluations," The GEF Independent Evaluation Office, Evaluation Document N.3.

GEF (2014a), "What is the GEF," Available on the GEF webpage, accessed January 28, 2014 at http://www.thegef.org/gef/whatisgef. 
GEF (2014b), "Report of the Sixth Replenishment of the GEF Trust Fund," Prepared by the GEF Secretariat and the World Bank as Trustee, GEF/A.2/07/Rev.01.

GEF (2014c), “Co-Financing Policy,” Prepared by the GEF Secretariat, GEF Policy: FI/PL/01.

GEF (2014d), “GEF-6 Indicative STAR Allocations,” GEF/C.47/Inf.08, July 1.

Guillaumont, P and R. Laajaj (2006) "When Instability Increases the Effectiveness of Aid Projects," World Bank Policy Research Working Group Paper No. 4034.

Harms, P. and M. Lutz (2006) "Aid, Governance and Private Foreign Investment: Some Puzzling Findings for the 1990s," The Economic Journal, 116:773-790.

Herzer, D. and M. Grimm (2012) "Does Foreign Aid Increase Private Investment? Evidence from Panel Cointegration," Applied Economics, 44:2537-2550.

International Monetary Fund (2014), External Debt Statistics: Guide for Compilers and Users, Washington, DC: IMF Publication Services.

Isham, J. and D. Kaufmann (1999) "The Forgotten Rationale for Policy Reform: The Productivity of Investment Projects,” Quarterly Journal of Economics, 114:149-184.

Isham, J., D. Kaufmann, L. Prichett (1997) "Civil Liberties, Democracy, and the Outcome of Government Projects,” World Bank Economic Review, 11:219-242.

Khwaja, I. (2009) "Can Good Projects Succeed in Bad Communities?" Journal of Public Economics, 93:899-916.

Kilby, C. (2000) "Supervision and Outcome: The Case of World Bank Projects," Journal of Development Economics, 62:233-259.

Miller, S. and B. Yu (2012) "Mobilizing Resources for Supporting Environmental Activities in Developing Countries: The Case of the GEF Trust Fund," IDB Working Paper Series, N. IDB-WP-329.

Papanek, G. (1973) “Aid, Foreign Private Investment, Savings, and Growth is Less Developed Countries," Journal of Political Economy, 81:120-130.

Sachs, J. D. (2005), The End of Poverty: Economic Possibilities for Our Time, New York, New York: The Penguin Press.

Selaya, P. and E. Sunesen (2012) "Does Foreign Aid Increase Foreign Direct Investment?" World Development, 40:2155-2176. 
Venugopal, S. and A. Srivastava (2012), Moving the Fulcrum: A Primer on Public Climate Financing Instruments Used to Leverage Private Capital, World Resources Institute, Working Paper, August 2012.

Wooldridge, J. M. (2002), Econometric Analysis of Cross Section and Panel Data, Cambridge Massachusetts: The MIT Press.

World Bank (2014), Additions to IDA Resources: Seventeenth Replenishment - IDA17: Maximizing Development Impact. Washington, DC: World Bank Group. 


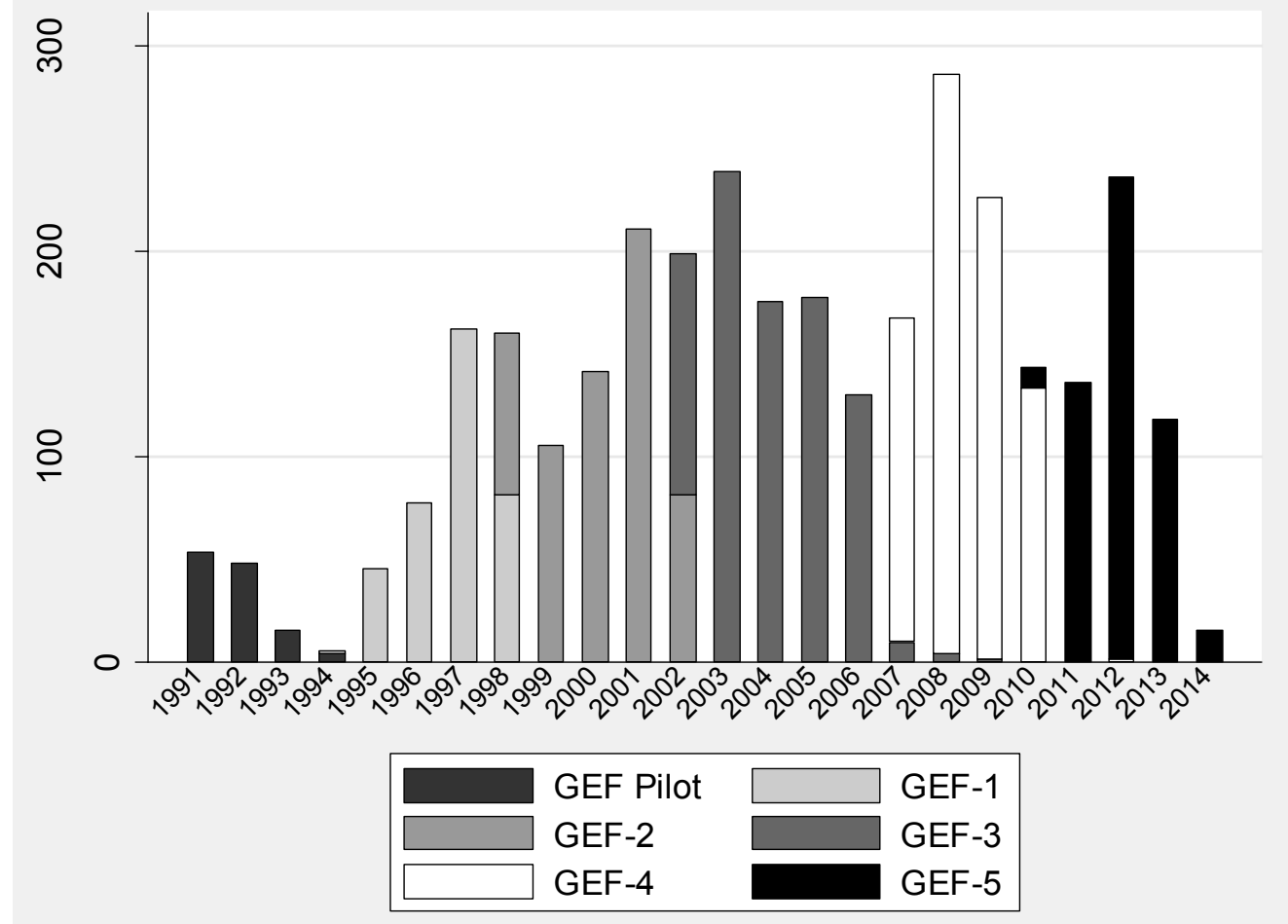

Figure 1: Number of GEF projects by year of approval and GEF phase, with a total of 3,269 projects 
Table 1: Descriptive statistics on financing and country characteristics

\begin{tabular}{lccccc}
\hline \hline Variable & Mean & Std. Dev. & Min & Max & Obs. \\
\hline \multicolumn{2}{l}{ Ganel A: GEF grant and cofinancing variables } & & & & \\
GEF grant (\$ millions) & 3.33 & 5.99 & 0.01 & 134.62 & 3269 \\
Preparatory grant (1=yes) & 0.46 & 0.50 & 0.0 & 1.0 & 3269 \\
Cofinancing (\$ millions) & 15.96 & 57.90 & 0.0 & $1,303.60$ & 3269 \\
Cofinancing ratio & 2.99 & 7.21 & 0.0 & 133.14 & 3269 \\
& & & & & \\
Panel B: Country characteristics & 3,007 & 3,202 & 110 & 24,036 & 3055 \\
GDP per capita (2013 \$s) & 39.25 & 21.85 & 0 & 93.3 & 3082 \\
Voice and accountability (WGI) & 41.60 & 19.93 & 0 & 90.9 & 3070 \\
Government effectiveness (WGI) & 41.40 & 20.00 & 0 & 96.6 & 3072 \\
Regulatory quality (WGI) & 39.12 & 20.57 & 0 & 92.2 & 3070 \\
Control of corruption (WGI) & & & 0.07 \\
\hline \hline
\end{tabular}

Note: Data for all observations are reported here, but in the statistical analysis we trim outliers on the upper end of the GEF grant and cofinancing ratio. Eliminating the upper on percent leaves a maximum of $\$ 27$ million for the GEF grant and 36 for the cofinancing ratio.

Table 2: Descriptive statistics on project categorical variables

\begin{tabular}{lclc}
\hline \hline Variable & Percentage & Variable & Percentage \\
\hline Project Type & & Lead agency & \\
Full-sized project & 46.6 & UN Development Programme (UNDP) & 48.3 \\
Medium-sized project & 20.6 & World Bank & 22.0 \\
Enabling activity & 32.8 & UN Environment Program (UNEP) & 18.5 \\
& & UN Industrial Development Org. (UNIDO) & 5.4 \\
Focal area & & Food and Agriculture Organization (FAO) & 1.2 \\
Biodiversity & 36.6 & Asian Development Bank (ADB) & 1.1 \\
Climate change & 30.8 & International Fund for Ag. Development (IFAD) & 1.2 \\
Multi-focal area & 12.5 & Inter-American Development Bank (IADB) & 1.0 \\
Persistent organic pollutants & 9.2 & Other agency & 1.3 \\
International waters & 5.8 & & \\
Land degradation & 4.2 & Region & 31.3 \\
Ozone depleting substances & 0.9 & Africa & 24.7 \\
& & Asia & 20.3 \\
Executing partner type & & Latin America / Caribbean & 16.1 \\
Government & 76.0 & Europe / Central Asia & 7.6 \\
Multilateral agency & 14.7 & Global (more than 1 region) & \\
NGO/Foundation/Institute & 8.5 & & \\
Private sector & 0.8 & & \\
\hline \hline
\end{tabular}

Note: Percentages based on 3,269 projects and may not sum to 100 due to rounding. 
Table 3: Regression models explaining differences in cofinancing ratios at project approval

\begin{tabular}{|c|c|c|c|c|}
\hline & (1) & $(2)$ & (3) & (4) \\
\hline & & OLS Fixed & & Random \\
\hline & OLS & Effects & Tobit & Effects Tobit \\
\hline \multirow[t]{2}{*}{ GEF grant (In) } & $0.414 * * *$ & $0.452 * * *$ & $0.473 * * *$ & $0.488 * * *$ \\
\hline & $(0.070)$ & $(0.074)$ & $(0.060)$ & $(0.061)$ \\
\hline \multirow[t]{2}{*}{ Preparatory grant (1=yes) } & 0.065 & 0.019 & 0.137 & 0.096 \\
\hline & $(0.215)$ & $(0.213)$ & $(0.148)$ & $(0.124)$ \\
\hline \multirow[t]{2}{*}{ Enabling activity (1=yes) } & $-1.156 * * *$ & $-1.078 * * *$ & $-1.118 * * *$ & $-1.168 * * *$ \\
\hline & $(0.271)$ & $(0.263)$ & $(0.192)$ & $(0.200)$ \\
\hline \multicolumn{5}{|c|}{ Focal Areas (Multi-focal area omitted) } \\
\hline \multirow[t]{2}{*}{ - Biodiversity } & -0.147 & -0.236 & $-0.447 * * *$ & $-0.500 * * *$ \\
\hline & $(0.187)$ & $(0.191)$ & $(0.127)$ & $(0.160)$ \\
\hline \multirow[t]{2}{*}{ - Climate change } & $1.088 * * *$ & $0.976 * * *$ & $0.348 * *$ & $0.293^{*}$ \\
\hline & $(0.238)$ & $(0.253)$ & $(0.169)$ & $(0.164)$ \\
\hline \multirow[t]{2}{*}{ - International waters } & 0.753 & $1.285^{* *}$ & 0.188 & $0.436^{*}$ \\
\hline & $(0.525)$ & $(0.582)$ & $(0.327)$ & $(0.264)$ \\
\hline \multirow[t]{2}{*}{ - Land degradation } & 0.913 & 0.821 & 0.380 & 0.333 \\
\hline & $(0.560)$ & $(0.549)$ & $(0.362)$ & $(0.265)$ \\
\hline \multirow[t]{2}{*}{ - Ozone related } & $-1.652 * * *$ & $-1.675 * * *$ & $-1.026 * * *$ & $-1.037^{* *}$ \\
\hline & $(0.383)$ & $(0.531)$ & $(0.248)$ & $(0.516)$ \\
\hline \multirow[t]{2}{*}{ - Organic pollutants } & $-0.773 * *$ & $-1.015^{* * *}$ & $-0.614 * * *$ & $-0.704 * * *$ \\
\hline & $(0.336)$ & $(0.366)$ & $(0.234)$ & $(0.225)$ \\
\hline \multicolumn{5}{|l|}{ Lead Agency (UNDP omitted) } \\
\hline \multirow[t]{2}{*}{$-A D B$} & $6.085^{* *}$ & $6.115^{* *}$ & $3.710 * *$ & $3.797 * * *$ \\
\hline & $(2.708)$ & $(2.524)$ & $(1.695)$ & $(0.508)$ \\
\hline \multirow[t]{2}{*}{ - FAO } & -0.585 & -0.330 & -0.419 & -0.321 \\
\hline & $(0.428)$ & $(0.441)$ & $(0.275)$ & $(0.418)$ \\
\hline \multirow[t]{2}{*}{$-I A D B$} & $1.355^{*}$ & $1.474 * *$ & 0.703 & 0.653 \\
\hline & $(0.781)$ & $(0.693)$ & $(0.515)$ & $(0.447)$ \\
\hline \multirow[t]{2}{*}{ - IFAD } & 0.079 & 0.067 & -0.086 & -0.120 \\
\hline & $(0.479)$ & $(0.485)$ & $(0.306)$ & $(0.408)$ \\
\hline \multirow[t]{2}{*}{ - UNEP } & $-0.319 * *$ & -0.035 & -0.050 & 0.051 \\
\hline & $(0.142)$ & $(0.161)$ & $(0.112)$ & $(0.142)$ \\
\hline \multirow[t]{2}{*}{ - UNIDO } & 0.257 & 0.439 & -0.185 & -0.080 \\
\hline & $(0.306)$ & $(0.306)$ & $(0.213)$ & $(0.247)$ \\
\hline \multirow[t]{2}{*}{ - World Bank } & $1.292 * * *$ & $1.278^{* * *}$ & $0.866 * * *$ & $0.856 * * *$ \\
\hline & $(0.317)$ & $(0.311)$ & $(0.201)$ & $(0.133)$ \\
\hline \multirow[t]{2}{*}{ - Other agency } & 0.922 & 0.889 & 0.631 & $0.675^{*}$ \\
\hline & $(0.847)$ & (0.799) & $(0.541)$ & (0.407) \\
\hline \multicolumn{5}{|c|}{ Executing partner type (Multilateral omitted) } \\
\hline \multirow[t]{2}{*}{ - Government } & 0.235 & -0.278 & 0.187 & -0.004 \\
\hline & $(0.289)$ & $(0.306)$ & $(0.210)$ & $(0.172)$ \\
\hline \multirow[t]{2}{*}{ - Private sector } & 0.071 & -0.385 & 0.117 & 0.006 \\
\hline & $(0.813)$ & $(0.920)$ & $(0.575)$ & $(0.566)$ \\
\hline - NGO/Foundation/Institution & -0.211 & -0.495 & 0.124 & 0.019 \\
\hline & $(0.351)$ & $(0.374)$ & $(0.243)$ & $(0.226)$ \\
\hline GDP per capita (In) & -0.037 & 0.458 & -0.040 & 0.067 \\
\hline & $(0.100)$ & $(0.323)$ & $(0.073)$ & $(0.055)$ \\
\hline Voice \& accountability (WGI) & $-0.012^{*}$ & -- & $-0.008^{*}$ & -- \\
\hline
\end{tabular}




\begin{tabular}{|c|c|c|c|c|}
\hline & $(0.007)$ & & $(0.005)$ & \\
\hline Government effectiveness (WGI) & $\begin{array}{c}0.020^{* *} \\
(0.008)\end{array}$ & -- & $\begin{array}{c}0.015^{* *} \\
(0.006)\end{array}$ & -- \\
\hline Regulatory quality (WGI) & $\begin{array}{l}0.014^{*} \\
(0.007)\end{array}$ & -- & $\begin{array}{c}0.008 \\
(0.006)\end{array}$ & -- \\
\hline Control of corruption (WGI) & $\begin{array}{c}-0.011^{*} \\
(0.007)\end{array}$ & -- & $\begin{array}{l}-0.005 \\
(0.005)\end{array}$ & -- \\
\hline \multicolumn{5}{|l|}{ Region (Global omitted) } \\
\hline - Africa & $\begin{array}{c}0.917 * * * \\
(0.306)\end{array}$ & -- & $\begin{array}{c}0.727^{* * *} \\
(0.228)\end{array}$ & -- \\
\hline - Asia & $\begin{array}{c}0.952 * * * \\
(0.293)\end{array}$ & -- & $\begin{array}{c}0.841^{* * *} \\
(0.212)\end{array}$ & -- \\
\hline - Europe/Central Asia & $\begin{array}{c}0.721^{* *} \\
(0.333)\end{array}$ & -- & $\begin{array}{c}0.720 * * * \\
(0.241)\end{array}$ & -- \\
\hline - Latin America/Caribbean & $\begin{array}{c}0.626 * * * \\
(0.218)\end{array}$ & -- & $\begin{array}{c}0.578 * * * \\
(0.168)\end{array}$ & -- \\
\hline Year dummies & Yes & Yes & Yes & Yes \\
\hline Country fixed effects & & Yes & & \\
\hline Observations & 2,978 & 2,990 & 2,978 & 2,990 \\
\hline R-squared (within) & 0.303 & 0.276 & & \\
\hline
\end{tabular}


Table 4: Linear probability models of loans and private sector involvement

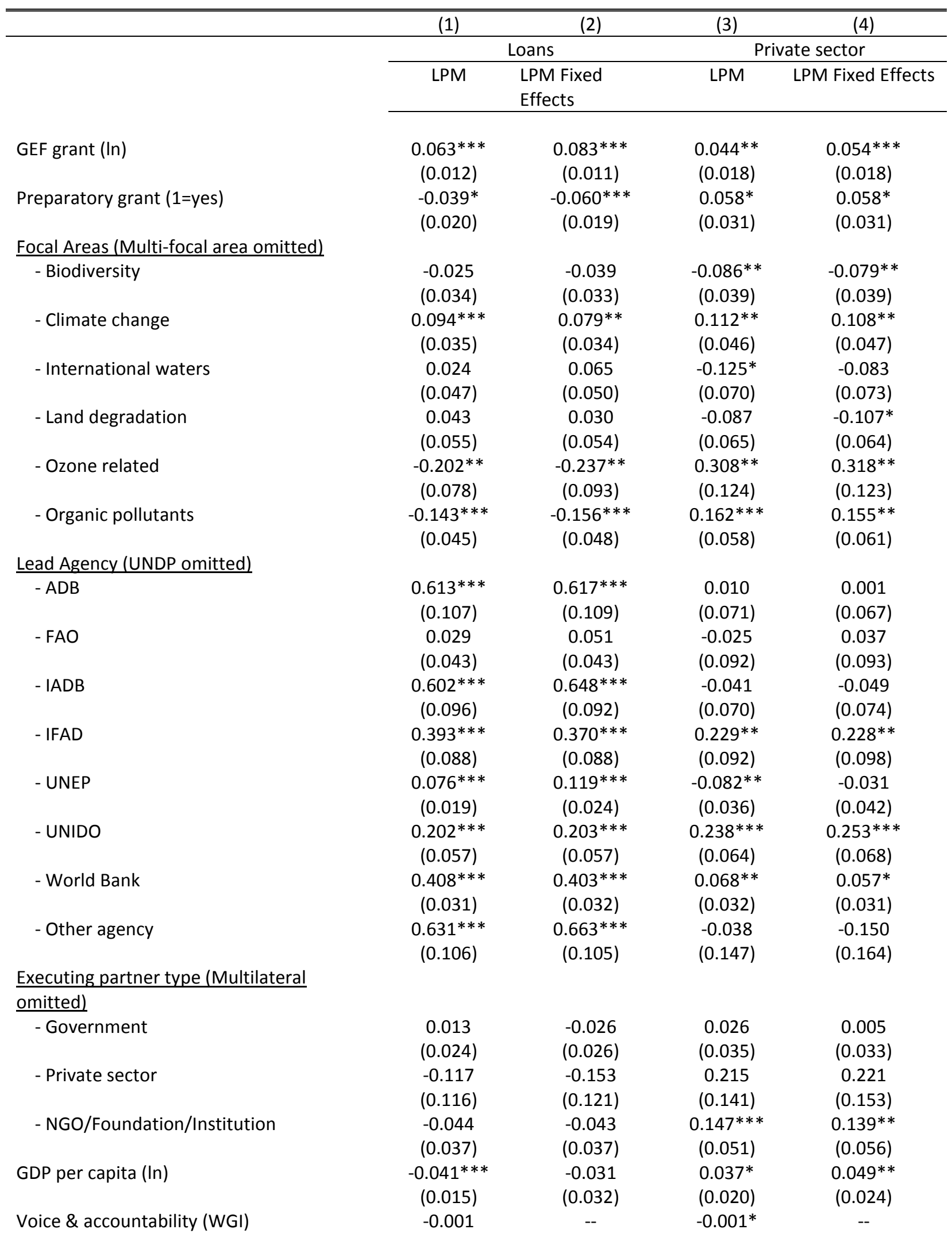




\begin{tabular}{|c|c|c|c|c|}
\hline & $(0.001)$ & & $(0.001)$ & \\
\hline Government effectiveness (WGI) & $\begin{array}{c}0.001 \\
(0.001)\end{array}$ & -- & $\begin{array}{l}0.003^{*} \\
(0.001)\end{array}$ & -- \\
\hline Regulatory quality (WGI) & $\begin{array}{c}0.001 \\
(0.001)\end{array}$ & -- & $\begin{array}{c}0.000 \\
(0.001)\end{array}$ & -- \\
\hline Control of corruption (WGI) & $\begin{array}{l}-0.001 \\
(0.001)\end{array}$ & -- & $\begin{array}{l}-0.001 \\
(0.001)\end{array}$ & -- \\
\hline \multicolumn{5}{|l|}{ Region (Global omitted) } \\
\hline - Africa & $\begin{array}{c}0.078 * * * \\
(0.028)\end{array}$ & -- & $\begin{array}{c}-0.062 \\
(0.038)\end{array}$ & -- \\
\hline - Asia & $\begin{array}{c}0.082 * * * \\
(0.026)\end{array}$ & -- & $\begin{array}{c}-0.113^{* * *} \\
(0.035)\end{array}$ & -- \\
\hline - Europe/Central Asia & $\begin{array}{c}0.155^{* * *} \\
(0.035)\end{array}$ & -- & $\begin{array}{l}-0.044 \\
(0.046)\end{array}$ & -- \\
\hline - Latin America/Caribbean & $\begin{array}{c}0.143^{* * *} \\
(0.026)\end{array}$ & -- & $\begin{array}{l}-0.051 \\
(0.032)\end{array}$ & -- \\
\hline Year dummies & Yes & Yes & Yes & Yes \\
\hline Country fixed effects & & Yes & & Yes \\
\hline Observations & 1,653 & 1,653 & 1,653 & 1,653 \\
\hline R-squared (within) & 0.379 & 0.381 & 0.141 & 0.119 \\
\hline
\end{tabular}


Table 5: Linear probability models of outcome and sustainability

\begin{tabular}{|c|c|c|c|c|c|c|}
\hline & \multicolumn{3}{|c|}{ Outcome } & \multicolumn{3}{|c|}{ Sustainability } \\
\hline & (1) & (2) & (3) & (4) & $(5)$ & (6) \\
\hline Cofinancing actual (In) & -- & $\begin{array}{c}0.032^{* * *} \\
(0.011)\end{array}$ & $\begin{array}{c}0.029 * * \\
(0.012)\end{array}$ & -- & $\begin{array}{c}0.027^{* *} \\
(0.013)\end{array}$ & $\begin{array}{l}0.024 * \\
(0.013)\end{array}$ \\
\hline $\begin{array}{l}\text { Cofinancing greater than expected } \\
\text { (1=yes) }\end{array}$ & --- & $\begin{array}{c}0.107^{* *} \\
(0.048)\end{array}$ & $\begin{array}{l}0.105^{* *} \\
(0.050)\end{array}$ & -- & $\begin{array}{c}0.110^{* * *} \\
(0.041)\end{array}$ & $\begin{array}{l}0.089 * \\
(0.047)\end{array}$ \\
\hline GEF grant (In) & $\begin{array}{l}-0.022 \\
(0.023)\end{array}$ & $\begin{array}{c}-0.055^{* *} \\
(0.027)\end{array}$ & $\begin{array}{c}-0.062 * * \\
(0.029)\end{array}$ & $\begin{array}{l}-0.017 \\
(0.022)\end{array}$ & $\begin{array}{c}-0.052^{* *} \\
(0.025)\end{array}$ & $\begin{array}{l}-0.054^{*} \\
(0.028)\end{array}$ \\
\hline Preparatory grant (1=yes) & $\begin{array}{c}-0.091 * * * \\
(0.033)\end{array}$ & $\begin{array}{c}- \\
0.096 * * * \\
(0.035)\end{array}$ & $\begin{array}{c}-0.090^{* *} \\
(0.039)\end{array}$ & $\begin{array}{l}0.042 \\
(0.039)\end{array}$ & $\begin{array}{c}0.014 \\
(0.044)\end{array}$ & $\begin{array}{l}0.032 \\
(0.048)\end{array}$ \\
\hline $\begin{array}{l}\text { Focal Areas (Multi-focal area } \\
\text { omitted) }\end{array}$ & & & & & & \\
\hline - Biodiversity & $\begin{array}{c}0.159 * * * \\
(0.059)\end{array}$ & $\begin{array}{c}0.145^{* *} \\
(0.067)\end{array}$ & $\begin{array}{c}0.176^{* *} \\
(0.080)\end{array}$ & $\begin{array}{c}0.110 \\
(0.080)\end{array}$ & $\begin{array}{l}0.076 \\
(0.088)\end{array}$ & $\begin{array}{c}0.079 \\
(0.098)\end{array}$ \\
\hline - Climate change & $\begin{array}{c}0.173 * * * \\
(0.064)\end{array}$ & $\begin{array}{l}0.143^{*} \\
(0.079)\end{array}$ & $\begin{array}{l}0.152^{*} \\
(0.091)\end{array}$ & $\begin{array}{c}0.260^{* * *} \\
(0.086)\end{array}$ & $\begin{array}{l}0.211^{* *} \\
(0.093)\end{array}$ & $\begin{array}{l}0.181^{*} \\
(0.104)\end{array}$ \\
\hline - International waters & $\begin{array}{c}0.144 \\
(0.104)\end{array}$ & $\begin{array}{c}0.125 \\
(0.138)\end{array}$ & $\begin{array}{l}0.173 \\
(0.110)\end{array}$ & $\begin{array}{c}0.252^{* * *} \\
(0.092)\end{array}$ & $\begin{array}{l}0.212^{*} \\
(0.108)\end{array}$ & $\begin{array}{l}0.176^{*} \\
(0.105)\end{array}$ \\
\hline - Land degradation & $\begin{array}{l}0.176 \\
(0.109)\end{array}$ & $\begin{array}{l}0.192^{*} \\
(0.107)\end{array}$ & $\begin{array}{l}0.282^{*} \\
(0.149)\end{array}$ & $\begin{array}{c}0.249 * * * \\
(0.091)\end{array}$ & $\begin{array}{l}0.168 \\
(0.105)\end{array}$ & $\begin{array}{c}0.226 \\
(0.150)\end{array}$ \\
\hline - Ozone related & $\begin{array}{l}0.206 \\
(0.162)\end{array}$ & $\begin{array}{c}0.177 \\
(0.190)\end{array}$ & $\begin{array}{c}0.208 \\
(0.200)\end{array}$ & $\begin{array}{c}0.504^{* * *} \\
(0.090)\end{array}$ & $\begin{array}{c}0.555^{* * *} \\
(0.097)\end{array}$ & $\begin{array}{c}0.539 * * * \\
(0.128)\end{array}$ \\
\hline - Organic pollutants & $\begin{array}{l}-0.052 \\
(0.088)\end{array}$ & $\begin{array}{l}-0.106 \\
(0.083)\end{array}$ & $\begin{array}{c}0.044 \\
(0.145)\end{array}$ & $\begin{array}{l}-0.143 \\
(0.087)\end{array}$ & $\begin{array}{c}-0.221^{* *} \\
(0.111)\end{array}$ & $\begin{array}{l}-0.021 \\
(0.154)\end{array}$ \\
\hline Lead Agency (Other agency omitted & & & & & & \\
\hline - UNDP & $\begin{array}{l}-0.057 \\
(0.173)\end{array}$ & $\begin{array}{l}-0.178 \\
(0.152)\end{array}$ & $\begin{array}{l}-0.173 \\
(0.150)\end{array}$ & $\begin{array}{c}- \\
0.395^{* * *} \\
(0.143)\end{array}$ & $\begin{array}{c}-0.376 * * \\
(0.172)\end{array}$ & $\begin{array}{c}-0.365 * * \\
(0.169)\end{array}$ \\
\hline - UNEP & $\begin{array}{l}-0.044 \\
(0.147)\end{array}$ & $\begin{array}{l}-0.160 \\
(0.127)\end{array}$ & $\begin{array}{l}-0.198 \\
(0.142)\end{array}$ & $\begin{array}{l}-0.285^{*} \\
(0.145)\end{array}$ & $\begin{array}{l}-0.261 \\
(0.159)\end{array}$ & $\begin{array}{l}-0.218 \\
(0.164)\end{array}$ \\
\hline - UNIDO & $\begin{array}{c}0.077 \\
(0.253)\end{array}$ & $\begin{array}{l}-0.043 \\
(0.222)\end{array}$ & $\begin{array}{l}-0.214 \\
(0.254)\end{array}$ & $\begin{array}{l}-0.014 \\
(0.210)\end{array}$ & $\begin{array}{c}0.006 \\
(0.213)\end{array}$ & $\begin{array}{l}-0.200 \\
(0.243)\end{array}$ \\
\hline - World Bank & $\begin{array}{l}-0.026 \\
(0.179)\end{array}$ & $\begin{array}{l}-0.168 \\
(0.151)\end{array}$ & $\begin{array}{l}-0.164 \\
(0.149)\end{array}$ & $\begin{array}{l}-0.256 \\
(0.155)\end{array}$ & $\begin{array}{l}-0.254 \\
(0.183)\end{array}$ & $\begin{array}{l}-0.250 \\
(0.183)\end{array}$ \\
\hline $\begin{array}{l}\text { Executing partner type (Multilateral } \\
\text { omitted) }\end{array}$ & & & & & & \\
\hline - Government & $\begin{array}{l}0.041 \\
(0.076)\end{array}$ & $\begin{array}{c}0.040 \\
(0.080)\end{array}$ & $\begin{array}{l}0.035 \\
(0.086)\end{array}$ & $\begin{array}{c}0.051 \\
(0.046)\end{array}$ & $\begin{array}{l}0.053 \\
(0.048)\end{array}$ & $\begin{array}{l}0.027 \\
(0.053)\end{array}$ \\
\hline - Private sector & $\begin{array}{l}-0.403^{* *} \\
(0.154)\end{array}$ & $\begin{array}{c}-0.374 * * \\
(0.176)\end{array}$ & $\begin{array}{l}-0.314^{*} \\
(0.167)\end{array}$ & $\begin{array}{l}-0.234 \\
(0.181)\end{array}$ & $\begin{array}{l}-0.288 \\
(0.185)\end{array}$ & $\begin{array}{l}-0.313^{*} \\
(0.185)\end{array}$ \\
\hline - NGO/Foundation/Institution & $\begin{array}{c}0.068 \\
(0.083)\end{array}$ & $\begin{array}{c}0.033 \\
(0.085)\end{array}$ & $\begin{array}{c}0.041 \\
(0.099)\end{array}$ & $\begin{array}{c}0.024 \\
(0.052)\end{array}$ & $\begin{array}{l}-0.016 \\
(0.053)\end{array}$ & $\begin{array}{c}0.000 \\
(0.066)\end{array}$ \\
\hline GDP per capita (In) & -- & -- & $\begin{array}{l}0.066^{*} \\
(0.034)\end{array}$ & -- & -- & $\begin{array}{c}0.054 \\
(0.040)\end{array}$ \\
\hline Voice \& accountability (WGI) & -- & -- & $\begin{array}{l}-0.002 \\
(0.002)\end{array}$ & -- & -- & $\begin{array}{c}0.001 \\
(0.002)\end{array}$ \\
\hline Government effectiveness (WGI) & -- & -- & -0.002 & -- & -- & 0.004 \\
\hline
\end{tabular}




\begin{tabular}{|c|c|c|c|c|c|c|}
\hline & & & $(0.003)$ & & & $(0.003)$ \\
\hline Regulatory quality (WGI) & -- & -- & $\begin{array}{c}0.005^{* *} \\
(0.002)\end{array}$ & -- & -- & $\begin{array}{c}-0.000 \\
(0.003)\end{array}$ \\
\hline Control of corruption (WGI) & -- & -- & $\begin{array}{c}0.000 \\
(0.002)\end{array}$ & -- & -- & $\begin{array}{c}0.000 \\
(0.002)\end{array}$ \\
\hline \multicolumn{7}{|l|}{ Region (Global omitted) } \\
\hline - Africa & $\begin{array}{c}-0.168 * * \\
(0.066)\end{array}$ & $\begin{array}{c}-0.156^{* *} \\
(0.072)\end{array}$ & $\begin{array}{c}- \\
0.250^{* * *} \\
(0.083)\end{array}$ & $\begin{array}{l}-0.072 \\
(0.044)\end{array}$ & $\begin{array}{c}-0.117 * * \\
(0.050)\end{array}$ & $\begin{array}{c}- \\
0.171^{* * *} \\
(0.056)\end{array}$ \\
\hline - Asia & $\begin{array}{l}-0.019 \\
(0.077)\end{array}$ & $\begin{array}{c}0.006 \\
(0.078)\end{array}$ & $\begin{array}{l}-0.089 \\
(0.087)\end{array}$ & $\begin{array}{c}0.041 \\
(0.080)\end{array}$ & $\begin{array}{c}0.057 \\
(0.071)\end{array}$ & $\begin{array}{l}-0.010 \\
(0.070)\end{array}$ \\
\hline - Europe/Central Asia & $\begin{array}{c}0.029 \\
(0.081)\end{array}$ & $\begin{array}{c}0.015 \\
(0.081)\end{array}$ & $\begin{array}{c}-0.182^{* *} \\
(0.089)\end{array}$ & $\begin{array}{c}0.080 \\
(0.057)\end{array}$ & $\begin{array}{c}0.046 \\
(0.060)\end{array}$ & $\begin{array}{l}-0.066 \\
(0.063)\end{array}$ \\
\hline - Latin America/Caribbean & $\begin{array}{l}-0.042 \\
(0.097)\end{array}$ & $\begin{array}{l}-0.041 \\
(0.097)\end{array}$ & $\begin{array}{c}-0.264^{* *} \\
(0.110)\end{array}$ & $\begin{array}{l}0.101^{*} \\
(0.057)\end{array}$ & $\begin{array}{c}0.092 \\
(0.056)\end{array}$ & $\begin{array}{l}-0.092 \\
(0.062)\end{array}$ \\
\hline GEF Phase dummies & Yes & Yes & Yes & Yes & Yes & Yes \\
\hline Observations & 688 & 592 & 546 & 666 & 576 & 530 \\
\hline R-squared (within) & 0.054 & 0.078 & 0.113 & 0.085 & 0.101 & 0.159 \\
\hline
\end{tabular}


Appendix Table 1: Double hurdle models explaining differences in cofinancing ratios at project approval

\begin{tabular}{|c|c|c|c|c|}
\hline & (1) & $(2)$ & (3) & (4) \\
\hline & LPM & $\begin{array}{c}\text { Fixed Effects } \\
\text { LPM }\end{array}$ & OLS & $\begin{array}{l}\text { OLS Fixed } \\
\text { Effects }\end{array}$ \\
\hline GEF grant (In) & $\begin{array}{c}0.061 * * * \\
(0.007)\end{array}$ & $\begin{array}{c}0.063^{* * *} \\
(0.008)\end{array}$ & $\begin{array}{c}0.500^{* * *} \\
(0.098)\end{array}$ & $\begin{array}{c}0.571 * * * \\
(0.104)\end{array}$ \\
\hline Preparatory grant (1=yes) & $\begin{array}{c}0.041 * * * \\
(0.011)\end{array}$ & $\begin{array}{c}0.038 * * * \\
(0.010)\end{array}$ & $\begin{array}{l}-0.021 \\
(0.220)\end{array}$ & $\begin{array}{l}-0.051 \\
(0.221)\end{array}$ \\
\hline Enabling activity (1=yes) & $\begin{array}{c}-0.175^{* * *} \\
(0.026)\end{array}$ & $\begin{array}{c}-0.169 * * * \\
(0.027)\end{array}$ & $\begin{array}{c}-1.064^{* * *} \\
(0.269)\end{array}$ & $\begin{array}{c}-0.980 * * * \\
(0.278)\end{array}$ \\
\hline \multicolumn{5}{|c|}{ Focal Areas (Multi-focal area omitted) } \\
\hline - Biodiversity & $\begin{array}{c}-0.109 * * * \\
(0.014)\end{array}$ & $\begin{array}{c}-0.118^{* * *} \\
(0.015)\end{array}$ & $\begin{array}{l}-0.347^{*} \\
(0.201)\end{array}$ & $\begin{array}{c}-0.462^{* *} \\
(0.206)\end{array}$ \\
\hline - Climate change & $\begin{array}{c}-0.165^{* * *} \\
(0.016)\end{array}$ & $\begin{array}{c}-0.169 * * * \\
(0.017)\end{array}$ & $\begin{array}{c}1.344^{* * *} \\
(0.277)\end{array}$ & $\begin{array}{c}1.200 * * * \\
(0.304)\end{array}$ \\
\hline - International waters & $\begin{array}{c}-0.112 * * * \\
(0.026)\end{array}$ & $\begin{array}{c}-0.094 * * * \\
(0.027)\end{array}$ & $\begin{array}{c}0.714 \\
(0.548)\end{array}$ & $\begin{array}{c}1.267^{* *} \\
(0.592)\end{array}$ \\
\hline - Land degradation & $\begin{array}{c}-0.085^{* * *} \\
(0.021)\end{array}$ & $\begin{array}{c}-0.098 * * * \\
(0.022)\end{array}$ & $\begin{array}{l}0.979 * \\
(0.569)\end{array}$ & $\begin{array}{c}0.782 \\
(0.565)\end{array}$ \\
\hline - Ozone related & $\begin{array}{c}0.006 \\
(0.039)\end{array}$ & $\begin{array}{c}0.004 \\
(0.037)\end{array}$ & $\begin{array}{c}-1.673 * * * \\
(0.422)\end{array}$ & $\begin{array}{c}-1.636 * * * \\
(0.565)\end{array}$ \\
\hline - Organic pollutants & $\begin{array}{c}-0.049 * * \\
(0.019)\end{array}$ & $\begin{array}{c}-0.064^{* * *} \\
(0.020)\end{array}$ & $\begin{array}{c}-0.816^{* *} \\
(0.367)\end{array}$ & $\begin{array}{c}-1.100^{* * * *} \\
(0.405)\end{array}$ \\
\hline \multicolumn{5}{|l|}{ Lead Agency (UNDP omitted) } \\
\hline$-A D B$ & $\begin{array}{c}-0.051^{* *} \\
(0.021)\end{array}$ & $\begin{array}{l}-0.003 \\
(0.025)\end{array}$ & $\begin{array}{l}5.937^{* *} \\
(2.699)\end{array}$ & $\begin{array}{c}6.010^{* *} \\
(2.529)\end{array}$ \\
\hline$-F A O$ & $\begin{array}{l}-0.019 \\
(0.026)\end{array}$ & $\begin{array}{c}0.010 \\
(0.028)\end{array}$ & $\begin{array}{l}-0.594 \\
(0.435)\end{array}$ & $\begin{array}{l}-0.296 \\
(0.452)\end{array}$ \\
\hline$-I A D B$ & $\begin{array}{l}-0.043^{*} \\
(0.025)\end{array}$ & $\begin{array}{l}-0.021 \\
(0.028)\end{array}$ & $\begin{array}{l}1.214 \\
(0.747)\end{array}$ & $\begin{array}{l}1.293^{* *} \\
(0.640)\end{array}$ \\
\hline - IFAD & $\begin{array}{l}-0.032^{*} \\
(0.018)\end{array}$ & $\begin{array}{l}-0.033 \\
(0.024)\end{array}$ & $\begin{array}{l}-0.077 \\
(0.494)\end{array}$ & $\begin{array}{l}-0.129 \\
(0.512)\end{array}$ \\
\hline - UNEP & $\begin{array}{c}0.056^{* * *} \\
(0.016)\end{array}$ & $\begin{array}{c}0.061 * * * \\
(0.017)\end{array}$ & $\begin{array}{l}-0.341^{*} \\
(0.174)\end{array}$ & $\begin{array}{c}0.060 \\
(0.200)\end{array}$ \\
\hline - UNIDO & $\begin{array}{c}-0.135 * * * \\
(0.028)\end{array}$ & $\begin{array}{c}-0.109 * * * \\
(0.027)\end{array}$ & $\begin{array}{c}0.143 \\
(0.371)\end{array}$ & $\begin{array}{c}0.354 \\
(0.367)\end{array}$ \\
\hline - World Bank & $\begin{array}{l}-0.003 \\
(0.012)\end{array}$ & $\begin{array}{l}-0.001 \\
(0.013)\end{array}$ & $\begin{array}{c}1.421^{* * *} \\
(0.354)\end{array}$ & $\begin{array}{c}1.411^{* * *} \\
(0.355)\end{array}$ \\
\hline - Other agency & $\begin{array}{c}-0.032 \\
-0.051^{* *}\end{array}$ & $\begin{array}{l}-0.025 \\
-0.003\end{array}$ & $\begin{array}{c}1.174 \\
5.937^{* *}\end{array}$ & $\begin{array}{c}1.146 \\
6.010^{* *}\end{array}$ \\
\hline \multicolumn{5}{|c|}{ Executing partner type (Multilateral omitted) } \\
\hline - Government & $\begin{array}{c}0.000 \\
(0.015)\end{array}$ & $\begin{array}{l}-0.015 \\
(0.014)\end{array}$ & $\begin{array}{c}0.274 \\
(0.325)\end{array}$ & $\begin{array}{c}-0.334 \\
(0.351)\end{array}$ \\
\hline - Private sector & $\begin{array}{c}0.001 \\
(0.058)\end{array}$ & $\begin{array}{l}-0.010 \\
(0.059)\end{array}$ & $\begin{array}{c}0.227 \\
(0.896)\end{array}$ & $\begin{array}{l}-0.195 \\
(0.992)\end{array}$ \\
\hline - NGO/Foundation/Institution & $\begin{array}{c}0.056 * * * \\
(0.021)\end{array}$ & $\begin{array}{c}0.046 * * \\
(0.021)\end{array}$ & $\begin{array}{l}-0.028 \\
(0.379)\end{array}$ & $\begin{array}{c}-0.322 \\
(0.417)\end{array}$ \\
\hline GDP per capita (In) & $\begin{array}{l}-0.004 \\
(0.008)\end{array}$ & $\begin{array}{c}0.008 \\
(0.017)\end{array}$ & $\begin{array}{l}-0.034 \\
(0.115)\end{array}$ & $\begin{array}{c}0.492 \\
(0.363)\end{array}$ \\
\hline
\end{tabular}




\begin{tabular}{|c|c|c|c|c|}
\hline Voice \& accountability (WGI) & $\begin{array}{c}0.000 \\
(0.000)\end{array}$ & -- & $\begin{array}{l}-0.014^{*} \\
(0.008)\end{array}$ & -- \\
\hline Government effectiveness (WGI) & $\begin{array}{c}0.001 \\
(0.001)\end{array}$ & -- & $\begin{array}{l}0.018^{*} \\
(0.009)\end{array}$ & -- \\
\hline Regulatory quality (WGI) & $\begin{array}{l}-0.001 * \\
(0.001)\end{array}$ & -- & $\begin{array}{c}0.022^{* *} \\
(0.009)\end{array}$ & -- \\
\hline Control of corruption (WGI) & $\begin{array}{l}0.001^{*} \\
(0.001)\end{array}$ & -- & $\begin{array}{l}-0.013^{*} \\
(0.008)\end{array}$ & -- \\
\hline \multicolumn{5}{|l|}{ Region (Global omitted) } \\
\hline - Africa & $\begin{array}{l}0.034 * \\
(0.017)\end{array}$ & -- & $\begin{array}{c}0.946 * * * \\
(0.338)\end{array}$ & -- \\
\hline - Asia & $\begin{array}{c}0.062 * * * \\
(0.020)\end{array}$ & -- & $\begin{array}{c}1.050 * * * \\
(0.329)\end{array}$ & -- \\
\hline - Europe/Central Asia & $\begin{array}{c}0.070 * * * \\
(0.019)\end{array}$ & -- & $\begin{array}{c}0.804^{* *} \\
(0.381)\end{array}$ & -- \\
\hline - Latin America/Caribbean & $\begin{array}{c}0.044^{* * *} \\
(0.015)\end{array}$ & -- & $\begin{array}{c}0.668 * * * \\
(0.253)\end{array}$ & -- \\
\hline Year dummies & Yes & Yes & Yes & Yes \\
\hline Country fixed effects & & Yes & & Yes \\
\hline Observations & 2,978 & 2,990 & 2,436 & 2,440 \\
\hline R-squared (within) & 0.513 & 0.500 & 0.268 & 0.245 \\
\hline
\end{tabular}

